Sains Malaysiana 49(7)(2020): 1577-1583

http://dx.doi.org/10.17576/jsm-2020-4907-10

\title{
Physicochemical and Bread-making Properties of Flours from Sweet Potatoes with Different Flesh Colours
}

(Sifat Fizikokimia dan Pembuatan Roti daripada Tepung Ubi Keledek dengan Warna Isi yang Berbeza)

\author{
MOHAMMAD ZAHIRUL ISLAM, Ji-YOUNG Kim \& YOUNG-TACK LEE*
}

\begin{abstract}
Flour was prepared from Korean sweet potatoes (SPS) with different flesh colours (white, yellow/orange, and purple) and evaluated for physicochemical and pasting properties and their partial substitution for bread-making. SP tubers were soaked in sodium metabisulfite solution (anti-browning agent) and subjected to hot air drying, followed by grinding. SP flours with different colours showed variations in chemical compositions, especially amylose, dietary fibre, and starch contents. Yellow/orange-fleshed SP flour had the highest content of total carotenoid (5.26 mg/100 g) among all SP flours. The highest total anthocyanin content $(59.92 \mathrm{mg} / 100 \mathrm{~g})$ was reported for purple-fleshed SP flour. Water absorption index (WAI), water solubility index (WSI), and an oil absorption of purple-fleshed SP flour were 1.63 $\mathrm{g} / \mathrm{g}, 25.59 \%$, and $187.21 \%$, respectively, and relatively higher than those of white or yellow/orange-fleshed SP flour. Wheat flour was substituted with SP flour in bread at 10-30\% level. The increase in the proportion of SP flour resulted in a significant decrease in loaf volume, and maximum reduction in loaf volume was reported for the bread containing purple-fleshed SP flour. However, SP flour may serve as a substitute for wheat flour at levels up to 10\% without causing any deteriorating effects on the overall bread quality. Therefore, coloured SP flour could be useful in the bread-making industry to improve the nutritional value of bread.
\end{abstract}

Keywords: Anthocyanin; bread-making; carotenoid; coloured sweet potato; physicochemical properties

\section{ABSTRAK}

Tepung disediakan daripada ubi keledek Korea (SP) dengan isi yang berbeza warna (putih, kuning/oren dan ungu) dan dinilai sifat fizikokimia dan adunannya serta penggantian separanya untuk pembuatan roti. Umbi SP direndam dalam larutan natrium metabisulfit (agen anti-pencoklatan) dan mengalami pengeringan udara panas, diikuti dengan pengisaran. Tepung SP dengan warna yang berbeza menunjukkan variasi dalam komposisi kimia, terutama amilosa, serat makanan dan kandungan kanji. Tepung SP berisi warna kuning/oren mempunyai kandungan karotenoid tertinggi $(5.26 \mathrm{mg} / 100 \mathrm{~g})$ antara semua tepung SP. Jumlah kandungan antosianin tertinggi (59.92 $\mathrm{mg} / 100 \mathrm{~g})$ dilaporkan untuk tepung SP berisi warna ungu. Indeks penyerapan air (WAI), indeks kelarutan air (WSI), dan penyerapan minyak tepung $S P$ berisi warna ungu masing-masing adalah $1.63 \mathrm{~g} / \mathrm{g}, 25.59 \%$ dan $187.21 \%$ dan relatif lebih tinggi daripada tepung SP dengan isi berwarna putih atau kuning/oren. Tepung gandum diganti dengan tepung SP dalam roti pada kadar 10$30 \%$. Peningkatan bahagian tepung SP menghasilkan penurunan isi padu roti yang ketara dan penurunan maksimum jumlah roti dilaporkan untuk roti yang mengandungi tepung SP berisi warna ungu. Walau bagaimanapun, tepung SP dapat berfungsi sebagai pengganti tepung gandum pada kadar hingga 10\% tanpa menyebabkan kesan buruk pada kualiti roti secara keseluruhan. Oleh itu, tepung SP berwarna boleh digunakan dalam industri pembuatan roti untuk meningkatkan nilai pemakanan roti.

Kata kunci: Antosianin; karotenoid; pembuatan roti; sifat fizikokimia ubi keledek berwarna

\section{INTRODUCTION}

Sweet potatoes (SPs) (Ipomoea batatas (L.) Lam) are one of the most nutritious vegetables that are rich in calories, dietary fibres, minerals, vitamins, and antioxidants such as phenolic acids, anthocyanins, tocopherols, and $\beta$-carotene (Mohanraj \& Sivasankar 2014). Some varieties of SPs contain coloured pigments such as $\beta$-carotene and anthocyanin that exhibit antioxidant properties and have functions related to antioxidation, anticancer, and protection against night blindness, aging, and liver injury (Wang et al. 2018; Xu et al. 2018). The anthocyanins from purple SPs possess biological functions such as scavenging of free radicals, anti-mutagenicity, anticarcinogen activity, and anti-hypertensive effects (Ahmed et al. 2010a; Zhang et al. 2018).

Considering their high perishability, SP tubers are commonly converted into flour for preservation. 
Processing of SPs into flour is the most satisfactory method of creating a product that is not only functionally adequate but also remains stable for an extended period without spoilage (Hanim et al. 2014). These flours are used as ingredients and processing aids in food industries (Adeola \& Ohizua 2018; Ahmed et al. 2010b; Yadav et al. 2014).

In flour, the structural changes in SP constituents, including starch, can occur during the drying and milling process that influence functional properties such as pasting, viscosity, and solubility. Therefore, the functional properties of such flours are mainly dependent on the method of preparation (Yadav et al. 2014).

Physicochemical and functional properties of flours from different cultivars of SPs are widely studied. However, reports on the flour properties of coloured SP cultivars are few, and no study has evaluated their applications in bakery products. Therefore, this research work was carried out to investigate the physicochemical and pasting properties and their partial substitution for the bread-making of Korean SP flours.

\section{Materials AND MeTHODS}

\section{MATERIALS AND PREPARATION OF SP FLOUR}

Sweet potato (SP) samples were obtained from a local market and included a typical white (cream-fleshed) and two coloured (orange-fleshed and purple-fleshed) SPs that were cultivated in Korea. SPs were stored at $12{ }^{\circ} \mathrm{C}$ before use. SPs were cleaned and washed with water, manually peeled, cut into $10 \mathrm{~mm}$ thick cubes, soaked in two volumes of $0.3 \%$ sodium bisulfite $(\mathrm{w} / \mathrm{v})$ for $5 \mathrm{~min}$, dried at $65{ }^{\circ} \mathrm{C}$ for $12 \mathrm{~h}$, and ground in a hammer mill (Nonstop M, Daehwa Engineering Co., Cheonan, Korea) with a 120 mesh screen to obtain flour.

\section{CHEMICAL ANALYSIS}

The moisture, crude protein, fat, and ash contents of SP flour were determined by the Association of Official Analytical Chemists methods (AOAC 2016). Starch content was determined according to the American Association of Cereal Chemists method 76-11 (AACC 2000), while the amylose content was evaluated as per the protocol described by Juliano et al. (1981). A dietary fibre assay kit (Sigma Co., USA) was used to measure the total content of dietary fibre (Prosky et al. 1985).

\section{CAROTENOID ANALYSIS}

A sample containing $600 \mathrm{mg}$ of SP flour was placed in a $15 \mathrm{~mL}$ tube and treated with $3 \mathrm{~mL}$ of ethanol (70\%). The mixture was extracted in a water bath $\left(25^{\circ} \mathrm{C}\right)$ for $5 \mathrm{~min}$, and incubated with $0.12 \mathrm{~mL}$ of $80 \%$ potassium chloride $(\mathrm{KCl})$ for $10 \mathrm{~min}$. Cold distilled water $(1.5 \mathrm{~mL})$ and hexane $(1.5 \mathrm{~mL})$ were added, and the mixture was vortexed and centrifuged at $4{ }^{\circ} \mathrm{C}$ and $1,200 \mathrm{rpm}$ for $5 \mathrm{~min}$. The supernatant was removed, and the hexane layer $(4.5 \mathrm{~mL})$ was removed with nitrogen gas. About $250 \mu \mathrm{L}$ of methanoldichloromethane at 50-50 (v/v) was added to the dried vial, and the sample was analyzed with high-performance liquid chromatography (HPLC, Shimadzu, Kyoto, Japan). In HPLC analysis, a photodiode array detector (450 nm) was used in the presence of $92 \%$ methanol containing $10 \mathrm{mM}$ ammonium acetate as mobile phase A and $100 \%$ methyl tert-butyl ether as mobile phase B. The flow program was run at $70 \% \mathrm{~A} / 30 \% \mathrm{~B}(23 \mathrm{~min}), 59 \% \mathrm{~A} / 41 \% \mathrm{~B}$ (29 min), $30 \% \mathrm{~A} / 70 \% \mathrm{~B}(40 \mathrm{~min}), 83 \% \mathrm{~A} / 17 \% \mathrm{~B}$ (44 min) and $83 \%$ $\mathrm{A} / 17 \% \mathrm{~B}(55 \mathrm{~min})$ at a flow rate of $1.0 \mathrm{~mL} / \mathrm{min}$ and a column temperature of $40^{\circ} \mathrm{C}$.

\section{ANTHOCYANIN ANALYSIS}

The content of monomeric anthocyanin in each sample was determined according to Lee et al. (2005) with a spectrophotometric (Shimadzu Corporation, Tokyo, Japan) $\mathrm{pH}$ differential protocol. About $2 \mathrm{~g}$ of the SP flour sample was extracted with $80 \%$ methanol containing $1 \%$ hydrochloric acid $(\mathrm{HCl})(18 \mathrm{~mL})$ in a shaking water bath $\left(25^{\circ} \mathrm{C}, 120 \mathrm{rpm}\right)$ for $2 \mathrm{~h}$ and centrifuged at 3,000 rpm for $15 \mathrm{~min}$. About $10 \mathrm{~mL}$ of the centrifuged supernatant was diluted with $0.025 \mathrm{M} \mathrm{KCl}-\mathrm{HCl}$ buffer ( $\mathrm{pH} 1.0)$ and $0.4 \mathrm{M}$ sodium acetate buffer $(\mathrm{pH} 4.5)$, and the volume was adjusted to $50 \mathrm{~mL}$. After $15 \mathrm{~min}$ of reaction, the absorbance of the solution was measured at $510 \mathrm{~nm}$ and $700 \mathrm{~nm}$ wavelengths. The anthocyanin content was calculated by substituting the measured values into the following equation:

Total monomeric anthocyanin $(\mathrm{mg} / \mathrm{mL})=(\mathrm{A} \times \mathrm{MW} \times$ dilution ratio $\times 1000) / \varepsilon$

where $A=\left(A_{510 \mathrm{~nm}}-\mathrm{A}_{700 \mathrm{~nm}}\right)_{\mathrm{pH} 1.0}-\left(\mathrm{A}_{510 \mathrm{~nm}}-\mathrm{A}_{700 \mathrm{~nm}}\right)_{\mathrm{pH} 4.5}$

MW is the molecular weight of cyanidin 3-glucoside (449.2), and $\varepsilon$ is molar absorptivity $(26,900)$.

\section{COLOUR AND PARTICLE SIZE ANALYSES}

The colour of SP flour was measured with a colorimeter (CR-200, Minolta, Osaka, Japan) (Islam et al. 2019a, 2019b). Particle size distribution was evaluated with a test sieve shaker (HAVER EML 200 digital plus, Germany) using a series of five selected US standard sieves (Nos. 60, 100, 140, 200, and 325, corresponding to sieve opening dimensions of $250,150,106,75$, and 45 $\mu \mathrm{m}$, respectively) by sieving $100 \mathrm{~g}$ flour for $5 \mathrm{~min}$.

\section{WATER ABSORPTION INDEX (WAI), WATER SOLUBILITY INDEX (WSI), AND AN OIL ABSORPTION}

Water absorption and water solubility indices were measured by the method described by Anderson (1982). Oil absorption was evaluated according to the method of Lin et al. (1974). 


\section{PASTING PROPERTIES}

The pasting properties of wheat flour substituted with different levels of SP flour were measured using Rapid Visco-Analyzer (RVA; Newport Scientific, Sydney, Australia). Sample (3.5 g, 14\% moisture basis) was mixed with water $(25 \mathrm{~mL})$ in an aluminum cup. The mixture was agitated at $960 \mathrm{rpm}$ for $10 \mathrm{~s}$ and subsequently at $160 \mathrm{rpm}$ for heating and cooling. The temperature was maintained at $50{ }^{\circ} \mathrm{C}$ for $1 \mathrm{~min}$ and then raised to $95^{\circ} \mathrm{C}$ at a rate of $12.16{ }^{\circ} \mathrm{C} / \mathrm{min}$. The hot paste was held at $95{ }^{\circ} \mathrm{C}$ for $2.5 \mathrm{~min}$, cooled to $50{ }^{\circ} \mathrm{C}$ at a rate of $11.84{ }^{\circ} \mathrm{C} / \mathrm{min}$, and then maintained at $50{ }^{\circ} \mathrm{C}$ for $2.5 \mathrm{~min}$. Viscosity was expressed as a rapid viscosity unit (RVU).

\section{BREAD PREPARATION AND PROPERTIES}

The bread was prepared according to the optimized straight-dough bread-making method described in the AACC method 10-10B (AACC 2000), using 10\%, 20\%, and $30 \%$ substituted SP flour in wheat flour. The baking formula was based on flour weight, and ingredients included flour (100\%), sugar $(6 \%)$, shortening $(3 \%)$, nonfat dry milk $(3 \%)$, salt $(2 \%)$, yeast $(2 \%)$, and distilled water $(65 \%)$. Loaf volume was measured $1 \mathrm{~h}$ after baking by the rapeseed displacement method. Loaf weight was measured, and the specific volume was computed as loaf volume (cc)/loaf weight $(\mathrm{g})$. Bread hardness was determined with a texture analyzer (TA-XT2, Stable Micro Systems Co., USA) operated with a $40 \mathrm{~mm}$ diameter aluminum plunger at $0.5 \mathrm{~mm} / \mathrm{s}$ for a distance of $10 \mathrm{~mm}$ to compress the $20 \mathrm{~mm}$ thick bread sample.

\section{STATISTICAL ANALYSIS}

The statistical analysis was conducted by SPSS V. 16 (SPSS Inc., Chicago, USA) of Tukey test following the one-way ANOVA.

\section{RESULTS AND DISCUSSION}

\section{CHEMICAL COMPOSITION OF SP FLOUR}

The chemical composition of flours from SP with different flesh colour is presented in Table 1. The highest content of moisture, crude protein, ash, and total dietary fibre was observed in flour prepared from purple SP. The crude protein content of SP flour was maximum for purple-fleshed SP flour, followed by white and yellow/ orange-fleshed SP flour. Crude protein levels were consistent with those previously reported (Hanim et al. 2014). However, the crude protein content of purplefleshed SP flour was significantly higher than that previously reported (Kim et al. 2011), probably owing to the presence of more nitrogenous substances (Shekhar et al. 2015). Crude fat content was maximum in yellow/ orange-fleshed SP flour. The purple-fleshed SP flour showed higher ash and dietary fibre contents than white or even yellow/orange-fleshed SP flour. The high ash content of the purple-fleshed flour is indicative of the high level of calcium, iron, magnesium, potassium, and sodium (Torres et al. 2007). Besides, the sufficient content of dietary fibre suggests the suitability of this flour for the preparation of functional food (Adeola \& Ohizua 2018), as it reduces insulin response and postprandial blood glucose level (Trinidad et al. 2010).

TABLE 1. Chemical composition (\%) of flours from sweet potatoes with different flesh colours

\begin{tabular}{lccc}
\hline & \multicolumn{3}{c}{ Flesh Colour } \\
\cline { 2 - 4 } Content & White & Yellow/Orang & Purple \\
\hline Moisture & $6.61 \pm 0.68 \mathrm{a}^{z}$ & $5.07 \pm 0.77 \mathrm{~b}$ & $7.05 \pm 0.77 \mathrm{a}$ \\
Crude protein & $5.20 \pm 0.68 \mathrm{~b}$ & $4.15 \pm 0.73 \mathrm{~b}$ & $7.15 \pm 0.63 \mathrm{a}$ \\
Crude fat & $1.66 \pm 0.33 \mathrm{~b}$ & $2.45 \pm 0.29 \mathrm{a}$ & $2.23 \pm 0.23 \mathrm{a}$ \\
Ash & $2.71 \pm 0.27 \mathrm{~b}$ & $2.48 \pm 0.24 \mathrm{~b}$ & $3.93 \pm 0.39 \mathrm{a}$ \\
Total dietary fibre & $7.17 \pm 0.76 \mathrm{~b}$ & $3.76 \pm 0.53 \mathrm{c}$ & $9.97 \pm 0.77 \mathrm{a}$ \\
Starch & $52.52 \pm 2.85 \mathrm{a}$ & $48.19 \pm 2.42 \mathrm{ab}$ & $46.76 \pm 2.45 \mathrm{~b}$ \\
Amylose & $27.50 \pm 1.57 \mathrm{a}$ & $29.55 \pm 1.99 \mathrm{a}$ & $21.24 \pm 2.02 \mathrm{~b}$ \\
\hline
\end{tabular}

${ }^{2}$ Values are means of three replicate analyses at dry weight basis (mean \pm standard deviation). Means with the same alphabet in each row are not significantly different at $p \leq 0.05$ using the Tukey test 
White-fleshed SP flour exhibited higher content of starch than the yellow/orange- and purple-fleshed SP flour. However, the highest level of amylose was reported in the yellow/orange-fleshed flour, while the purplefleshed SP flour had the lowest amylose content.

\section{CAROTENOIDS AND ANTHOCYANIN OF SP FLOUR}

The levels of total carotenoids and anthocyanin in whiteyellow/orange- and purple-fleshed SP flours are shown in Table 2. Carotenoid is a fat-soluble and anthocyanin is a water-soluble flavonoid-based pigment that exhibits orange, yellow, purple, or red colour. Among the tested carotenoids, lutein, zeaxanthin, $\alpha$-carotene, and $\beta$-carotene content were present in significantly higher levels in yellow/orange-fleshed SP flour than in whiteand purple-fleshed SP flours. The yellow/orange-fleshed SP flour was shown to exhibit more total carotenoids than white/purple-, yellow/purple-, and white/yellow/ purple-fleshed SP flour (Grace et al. 2014; Kim et al. 2011; Tang et al. 2015). No zeaxanthin was found in purple-fleshed SP flour, and the levels of the other three carotenoids were also low (Table 2). Kammona et al. (2015) failed to detect lutein, zeaxanthin, and $\alpha$-carotene in purple-fleshed SP. The contents of $\alpha$ - and $\beta$-carotenes were substantially higher in yellow/orange-fleshed SP flour than in other flours, as anticipated. The level of total anthocyanin was the highest in purple-fleshed SP flour $(59.92 \mathrm{mg} / 100 \mathrm{~g})$ among the three flour types. Higher anthocyanin content was reported in purple-fleshed SP flour than in white/orange-, yellow/orange-, and white/ yellow/purple-fleshed SP flours (Grace et al. 2014; Kim et al. 2011; Tang et al. 2015). However, the carotenoid and anthocyanin contents of SP were shown to be affected by varieties/genotypes, growth environment, flesh colour, harvest time, storage period, boiling, and drying conditions (Grace et al. 2014; Liu et al. 2009; Shekhar et al. 2015).

TABLE 2. Carotenoid and total anthocyanin contents of flours from sweet potatoes with different flesh colour

\begin{tabular}{lccccc}
\hline \multirow{2}{*}{ Sweet potato } & \multicolumn{4}{c}{ Carotenoid $(\mu \mathrm{g} / 100 \mathrm{~g})$} & $\begin{array}{c}\text { Total } \\
\text { anthocyanin } \\
(\mathrm{mg} / 100 \mathrm{~g})\end{array}$ \\
\cline { 2 - 5 } White & Lutein & Zeaxanthin & $\alpha$-Carotene & $\beta$-Carotene & $1.61 \pm 0.49 \mathrm{~b}$ \\
Yellow/Orange & $553.30 \pm 6.02 \mathrm{a}$ & $53.90 \pm 0.79 \mathrm{a}$ & $416.87 \pm 2.09 \mathrm{a}$ & $4237.10 \pm 76.53 \mathrm{a}$ & $0.84 \pm 0.16 \mathrm{~b}$ \\
Purple & $18.79 \pm 0.23 \mathrm{c}$ & $0.00 \pm 0.00 \mathrm{c}$ & $7.12 \pm 0.17 \mathrm{c}$ & $31.11 \pm 1.48 \mathrm{~b}$ & $59.92 \pm 13.04 \mathrm{a}$ \\
\hline
\end{tabular}

${ }^{2}$ Values are means of three replicate analyses at dry weight basis (mean \pm standard deviation). Means with the same alphabet in each column are not significantly different at $p \leq 0.05$ using the Tukey test

\section{PARTICLE SIZE DISTRIBUTION AND COLOUR}

The particle size distribution of different flour types, as determined with sieve shaker, is presented in Table 3. Grinding is accompanied by the action of various physical forces such as compression, shearing, impact, friction, and twisting, and the resulting flour is composed of particles of various sizes. The particle size of ground
SP samples expressed as particle size distribution varies depending on the type of raw material, type of grinder, and grinding methods. According to mesh size, the particle size distribution varied for different coloured SP flours (Table 3). The particle size was relatively smaller for white- and orange-fleshed SP flours, but, larger particle sizes were reported for purple-fleshed SP flour.

TABLE 3. Particle size distribution (\%) of flours from sweet potatoes with different flesh colours

\begin{tabular}{|c|c|c|c|c|c|c|}
\hline \multirow{2}{*}{ Sweet potato } & \multicolumn{6}{|c|}{ Mesh Size } \\
\hline & +60 & +100 & +140 & +200 & +325 & -325 \\
\hline White & $0.67 \pm 0.16 \mathrm{a}^{\mathrm{z}}$ & $2.33 \pm 0.43 b$ & $8.80 \pm 0.58 c$ & $15.82 \pm 0.46 b$ & $55.71 \pm 2.47 \mathrm{a}$ & $14.32 \pm 1.72 \mathrm{a}$ \\
\hline Yellow/Orange & $0.13 \pm 0.03 c$ & $2.59 \pm 0.39 b$ & $10.14 \pm 0.85 b$ & $16.32 \pm 0.75 b$ & $59.82 \pm 2.76 a$ & $9.31 \pm 1.24 b$ \\
\hline Purple & $0.46 \pm 0.07 b$ & $6.69 \pm 0.46 a$ & $15.70 \pm 0.63 a$ & $19.85 \pm 0.75 a$ & $48.23 \pm 2.84 b$ & $5.91 \pm 0.47 \mathrm{c}$ \\
\hline
\end{tabular}

${ }^{2}$ Values are means of three replicate analyses at dry weight basis (mean \pm standard deviation). Means with the same alphabet in each column are not significantly different at $p \leq 0.05$ using the Tukey test 
The colour values of SP flours are presented in Table 4. The L* value of yellow/orange-fleshed SP flour was the highest, while the lowest $\mathrm{L}^{*}$ value was reported for purple-fleshed SP flour. The highest values of redness $\left(a^{*}\right)$ and yellowness $\left(b^{*}\right)$ were observed purple- and yellow/orange-fleshed SP flours, respectively. High $a^{*}$ and $b^{*}$ values confirmed the high content of anthocyanin and carotenoids in SPs, respectively. The changes in $\mathrm{a}^{*}$ and $b^{*}$ values may be associated with the anthocyanin and carotenoid contents (Shekhar et al. 2015; Wanjuu et al. 2018). The value of $a^{*}$ (greenness) was negative for white and yellow/orange-fleshed SP flours. The fleshed colour of SPs varied with cultivar type, browning reaction products, and concentration of colour pigments.

\section{WAI, WSI, AND AN OIL ABSORPTION}

The values of WAI, WSI, and an oil absorption of different SP flour types are presented in Table 4. The purple-fleshed SP flour showed the highest value of WAI, WSI, and oil absorption. WAI of flour depends on the hydrophobic tendency of starch and the cell wall materials (Iheagwara 2013; Singh et al. 2008). Yellow/ orange-fleshed SP flour showed the lowest value of WAI, probably owing to the relatively high-fat content. The value of WSI was the highest for the purple-fleshed SP flour, followed by yellow/orange- and white-fleshed SP flours. The high-water solubility of purple SP flour was possibly associated with the high content of proteins and dietary fibres. Oil absorption capacity was the highest for the purple-fleshed SP flour.

TABLE 4. Colour values, water absorption index (WAI), water solubility index (WSI), and an oil absorption of flours from sweet potatoes with different flesh colours

\begin{tabular}{|c|c|c|c|c|c|c|}
\hline \multirow{2}{*}{ Sweet potato } & \multicolumn{3}{|c|}{ Colour } & \multirow{2}{*}{$\begin{array}{l}\text { WAI } \\
(\mathrm{g} / \mathrm{g})\end{array}$} & \multirow{2}{*}{$\begin{array}{l}\text { WSI } \\
(\%)\end{array}$} & \multirow{2}{*}{$\begin{array}{c}\text { Oil absorption } \\
(\%)\end{array}$} \\
\hline & $\mathrm{L}^{*}$ & $a^{*}$ & $b^{*}$ & & & \\
\hline White & $85.77 \pm 1.29 b^{z}$ & $-12.28 \pm 1.02 b$ & $\begin{array}{c}+44.78 \pm \\
0.97 \mathrm{a}\end{array}$ & $1.40 \pm 0.08 b$ & $20.94 \pm 0.84 c$ & $180.70 \pm 1.60 \mathrm{~b}$ \\
\hline Yellow/Orange & $90.54 \pm 1.19 \mathrm{a}$ & $-13.64 \pm 1.29 b$ & $\begin{array}{c}+44.81 \pm \\
0.88 \mathrm{a}\end{array}$ & $1.20 \pm 0.07 \mathrm{c}$ & $22.95 \pm 0.77 b$ & $175.65 \pm 1.03 \mathrm{c}$ \\
\hline Purple & $51.97 \pm 0.83 \mathrm{c}$ & $+11.32 \pm 1.26 \mathrm{a}$ & $\begin{array}{c}+20.63 \pm \\
1.09 \mathrm{~b}\end{array}$ & $1.63 \pm 0.04 \mathrm{a}$ & $25.59 \pm 0.96 \mathrm{a}$ & $187.21 \pm 1.21 \mathrm{a}$ \\
\hline
\end{tabular}

${ }^{2}$ Values are means of replicates \pm standard deviation $(\mathrm{n}=3)$. Means with the same alphabet in each column are not significantly different at $p \leq 0.05$ using the Tukey test. $\mathrm{L}^{*}=$ lightness,$+\mathrm{a}^{*}=$ red; $-\mathrm{a}^{*}=$ greenness $;+\mathrm{b}^{*}=$ yellowness

\section{PASTING PROPERTIES OF WHEAT FLOUR SUBSTITUTED WITH SP FLOUR}

The effects of mixing SP flour at different concentrations $(0-30 \%)$ on the pasting properties of wheat flours are shown in Table 5. As the concentration of SP flour increased, the peak viscosity of wheat flour remarkably decreased. Yellow/orange-fleshed SP flour at all concentrations tested $(10,20$, and 30\%) showed peak viscosity values lower than those reported for the purple-fleshed or white-fleshed SP flour (Table 5). The sugar content in SPs increases in response to the action of starch hydrolyzing enzymes during the post-harvest storage or heating (Singh et al. 2010). The low values of peak viscosity may be associated with the action of starch degrading enzymes present in SP flour.

\section{PROPERTIES OF BREAD SUBSTITUTED WITH SP FLOURS}

Table 5 shows the baking properties of the bread substituted with different concentrations of white-, yellow/orange-, and purple-fleshed SP flours. In comparison with the control bread (100\% wheat flour), those containing $10 \%$ white-fleshed SP flour showed no significant difference in loaf volume ( $p \geq 0.05)$. However, the loaf volume considerably decreased with an increase in SP flour concentration beyond 10\%. Flour gluten has a significant role in the quality of bread (Hung et al. 2007). The substitution of wheat flour with SP flour may dilute the flour gluten, and lower the gas-holding capacity of the dough, thereby causing a decrease in bread volume. Loaf weight significantly increased with SP flour substitution at all tested concentrations. Specific loaf volume and hardness of bread were not significantly affected at $10 \%$ substitution except purple-fleshed SP flour. However, a substantial rise in hardness was observed at 20 and 30\% substitution as compared with the control samples. The loaf volume was significantly affected $(p \leq 0.05)$ for the bread substituted with yellow/orange-fleshed SP flour, at 20 and $30 \%$ levels of substitution. The maximum 
decrease in loaf volume and specific loaf volume was observed in the bread containing purple-fleshed SP flour. As the substitution level of SP flour increased, the bread showed inferior appearance with dense and rough surface texture. SP bread with smaller loaf volume was harder than the one with larger loaf volume, consistent with the observations reported by Basman et al. (2002). Therefore, SP flour may serve as a substitute for wheat flour at levels up to $10 \%$ to avoid any significant adverse effects on bread quality.

TABLE 5. Pasting properties of flour and baking properties of bread substituted with different levels of white-fleshed, yellow/ orange-fleshed, or purple-fleshed sweet potato flour

\begin{tabular}{|c|c|c|c|c|c|c|c|c|c|c|}
\hline \multirow[t]{2}{*}{ Properties } & \multirow[b]{2}{*}{ Control } & \multicolumn{3}{|c|}{$\begin{array}{c}\text { White-fleshed } \\
\text { sweet potato (\%) }\end{array}$} & \multicolumn{3}{|c|}{$\begin{array}{l}\text { Yellow/Orange-fleshed } \\
\text { sweet potato }(\%)\end{array}$} & \multicolumn{3}{|c|}{$\begin{array}{l}\text { Purple-fleshed } \\
\text { sweet potato }(\%)\end{array}$} \\
\hline & & 10 & 20 & 30 & 10 & 20 & 30 & 10 & 20 & 30 \\
\hline $\begin{array}{l}\text { Peak viscosity } \\
\text { (RVU) }\end{array}$ & $\begin{array}{l}203.0 \\
\pm 2.7 \mathrm{a}^{\mathrm{z}}\end{array}$ & $\begin{array}{l}40.8 \\
\pm 0.6 \mathrm{c}\end{array}$ & $\begin{array}{l}20.7 \\
\pm 1.1 \mathrm{e}\end{array}$ & $\begin{array}{l}18.9 \\
\pm 0.2 \mathrm{e}\end{array}$ & $\begin{array}{l}19.5 \\
\pm 0.4 \mathrm{e}\end{array}$ & $\begin{array}{l}14.4 \\
\pm 0.6 \mathrm{f}\end{array}$ & $\begin{array}{l}13.1 \\
\pm 0.2 \mathrm{f}\end{array}$ & $\begin{array}{l}50.8 \\
\pm 0.1 \mathrm{~b}\end{array}$ & $\begin{array}{l}27.0 \\
\pm 1.2 \mathrm{~d}\end{array}$ & $\begin{array}{l}19.8 \\
\pm 0.3 \mathrm{e}\end{array}$ \\
\hline $\begin{array}{l}\text { Loaf volume } \\
\text { (cc) }\end{array}$ & $\begin{array}{l}809.7 \\
\pm 70.7 \mathrm{a}\end{array}$ & $\begin{array}{l}767.5 \\
\pm 10.6 \mathrm{a}\end{array}$ & $\begin{array}{l}606.5 \\
\pm 19.1 \mathrm{~b}\end{array}$ & $\begin{array}{l}470.0 \\
\pm 21.2 \mathrm{c}\end{array}$ & $\begin{array}{l}725.0 \\
\pm 49.5 \mathrm{a}\end{array}$ & $\begin{array}{l}618.0 \\
\pm 17.0 \mathrm{~b}\end{array}$ & $\begin{array}{l}352.2 \\
\pm 31.8 \mathrm{de}\end{array}$ & $\begin{array}{l}428.0 \\
\pm 7.1 \mathrm{~cd}\end{array}$ & $\begin{array}{l}355.5 \\
\pm 3.5 \mathrm{de}\end{array}$ & $\begin{array}{l}298.0 \\
\pm 7.1 \mathrm{e}\end{array}$ \\
\hline $\begin{array}{l}\text { Loaf weight } \\
\text { (g) }\end{array}$ & $\begin{array}{l}166.1 \\
\pm 1.7 \mathrm{~g}\end{array}$ & $\begin{array}{l}175.1 \\
\pm 1.1 \mathrm{~cd}\end{array}$ & $\begin{array}{l}178.6 \\
\pm 0.4 \mathrm{~b}\end{array}$ & $\begin{array}{l}180.2 \\
\pm 0.1 \mathrm{ab}\end{array}$ & $\begin{array}{l}169.3 \\
\pm 0.6 \mathrm{fg}\end{array}$ & $\begin{array}{l}174.5 \\
\pm 0.2 \mathrm{~cd}\end{array}$ & $\begin{array}{l}182.0 \\
\pm 0.2 \mathrm{a}\end{array}$ & $\begin{array}{l}170.7 \\
\pm 0.2 \mathrm{ef}\end{array}$ & $\begin{array}{l}177.2 \\
\pm 0.2 \mathrm{bc}\end{array}$ & $\begin{array}{l}173.6 \\
\pm 3.0 \mathrm{de}\end{array}$ \\
\hline $\begin{array}{l}\text { Specific loaf } \\
\text { volume (cc/g) }\end{array}$ & $\begin{array}{l}4.9 \\
\pm 0.5 \mathrm{a}\end{array}$ & $\begin{array}{l}4.4 \\
\pm 0.0 \mathrm{ab}\end{array}$ & $\begin{array}{l}3.4 \\
\pm 0.1 \mathrm{c}\end{array}$ & $\begin{array}{l}2.6 \\
\pm 0.1 \mathrm{~d}\end{array}$ & $\begin{array}{l}4.3 \\
\pm 0.3 \mathrm{~b}\end{array}$ & $\begin{array}{l}3.5 \\
\pm 0.1 \mathrm{c}\end{array}$ & $\begin{array}{l}1.9 \\
\pm 0.2 \mathrm{f}\end{array}$ & $\begin{array}{l}2.5 \\
\pm 0.0 \mathrm{de}\end{array}$ & $\begin{array}{l}2.0 \\
\pm 0.0 \mathrm{ef}\end{array}$ & $\begin{array}{l}1.7 \\
\pm 0.1 \mathrm{f}\end{array}$ \\
\hline $\begin{array}{l}\text { Hardness } \\
\text { (gram force) }\end{array}$ & $\begin{array}{l}148.1 \\
\pm 19.8 \mathrm{e}\end{array}$ & $\begin{array}{l}178.3 \\
\pm 15.3 \mathrm{e}\end{array}$ & $\begin{array}{l}319.9 \\
\pm 16.1 \mathrm{~d}\end{array}$ & $\begin{array}{l}835.0 \\
\pm 74.8 \mathrm{~b}\end{array}$ & $\begin{array}{l}159.6 \\
\pm 8.6 \mathrm{e}\end{array}$ & $\begin{array}{l}309.2 \\
\pm 22.9 \mathrm{~d}\end{array}$ & $\begin{array}{l}1133.6 \\
\pm 39.0 \mathrm{a}\end{array}$ & $\begin{array}{l}245.8 \\
\pm 18.2 \mathrm{de}\end{array}$ & $\begin{array}{l}535.6 \\
\pm 24.9 \mathrm{c}\end{array}$ & $\begin{array}{l}829.9 \\
\pm 71.0 \mathrm{~b}\end{array}$ \\
\hline
\end{tabular}

${ }^{2}$ Values are means of replicates \pm standard deviation $(\mathrm{n}=5)$. Means with the same alphabet in each row are not significantly different at $p \leq 0.05$ using the Tukey test. Note: control $=100 \%$ wheat flour

\section{CONCLUSION}

This research work was carried out to investigate the physicochemical and pasting properties and their partial substitution for bread-making of white, yellow/orange, and purple-fleshed Korean SP flour sweet. The highest carotenoid and anthocyanin contents were observed for yellow/orange-fleshed and purple-fleshed SP flour, respectively. Flours from SPs with different flesh colours showed differences in proximate composition, starch and dietary fibre contents, and physicochemical properties. As a result of partial substitution effect on bread-making, SP flour could be added to replace wheat flour at levels up to $10 \%$ without significantly depressing the overall quality of bread. These findings may be useful in bread- making industries to improve the nutritional value of bread.

\section{ACKNOWLEDGEMENTS}

This work was supported by the Korea Institute of Planning and Evaluation for Technology in Food, Agriculture, Forestry (IPET), Ministry of Agriculture, Food and Rural Affairs (MAFRA). The authors confirmed that there is no conflict of interest.

\section{REFERENCES}

AACC. 2000. Approved Methods of Analysis. 10th ed. St Paul: AACC International. p. 1018.

Adeola, A.A. \& Ohizua, E.R. 2018. Physical, chemical, and sensory properties of biscuits prepared from flour blends of unripe cooking banana, pigeon pea, and sweet potato. Food Science \& Nutrition 6(3): 532-540.

Ahmed, M., Akter, M.S. \& Eun, J.B. 2010a. Impact of $\alpha$-amylase and maltodextrin on physicochemical, functional and antioxidant capacity of spray-dried purple sweet potato flour. Journal of the Science of Food and Agriculture 90(3): 494-502.

Ahmed, M., Akter, M.S. \& Eun, J.B. 2010b. Peeling, drying temperatures, and sulphite-treatment affect physicochemical properties and nutritional quality of sweet potato flour. Food Chemistry 121(1): 112-118.

Anderson, R.A. 1982. Water absorption and solubility and amylograph characteristics of roll-cooked small grain products. Cereal Chemistry 59: 265-269.

AOAC. 2016. Official Methods of Analysis of the Association of Official Analytical Chemists. 20th ed. Arlington, VA, USA.

Basman, A., Köksel, H. \& Ng, P.K.W. 2002. Effects of increasing levels of transglutaminase on the rheological properties and bread quality characteristics of two wheat flours. European Food Research and Technology 215: 419-424.

Grace, M.H., Yousef, G.G., Gustafson, S.J., Truong, V.D., Yencho, G.C. \& Lila, M.A. 2014. Phytochemical changes 
in phenolics, anthocyanins, ascorbic acid, and carotenoids associated with sweet potato storage and impacts on bioactive properties. Food Chemistry 145: 717-724.

Hanim, A.B.M., Chin, N.L. \& Yusof, Y.A. 2014. Physicochemical and flowability characteristics of a new variety of Malaysian sweet potato, VitAto flour. International Food Research Journal 21(5): 2099-2107.

Hung, P.V., Maeda, T. \& Morita, M. 2007. Dough and bread qualities of flours with whole waxy wheat flour substitution. Food Research International 40(2): 273-279.

Iheagwara, M.C. 2013. Isolation, modification and characterization of sweet potato (Ipomoea batatas L (Lam)) starch. Food Processing and Technology Open Access Journal 4(1): 1-6.

Islam, M.Z., Park, B.J. \& Lee, Y.T. 2019a. Effect of salinity stress on bioactive compounds and antioxidant activity of wheat microgreen extract under organic cultivation condition. International Journal of Biological Macromolecules 140: 631-636.

Islam, M.Z., An, H.G. \& Lee, Y.T. 2019b. Comparative analyses on the bioactive compounds and in vitro antioxidant capacity of tea infusions prepared from the selected medicinal fruits. Chemistry \& Biodiversity 16(12): e1900459.

Juliano, B.O., Perez, C.M., Blakeney, A.B., Castillo, D.T., Kongseree, N., Laignelet, B., Lapis, E.T., Murty, V.V.S., Paule, C.M. \& Webb, B.D. 1981. International cooperative testing on the amylose content of milled rice. Starch 33(5): 157-162.

Kammona, S., Othman, R., Jaswir, I. \& Jamal, P. 2015. Characterisation of carotenoid in diverse local sweet potato (Ipomoea batatas) flesh tubers. International Journal of Pharmacy and Pharmaceutical Sciences 7(2): 347-351.

Kim, J.M., Park, S.J., Lee, C.S., Ren, C., Kim, S.S. \& Shin, M. 2011. Functional properties of different Korean sweet potato varieties. The Food Science and Biotechnology 20(6): 1501-1507.

Lee, J., Durst, R.W. \& Wrolstad, R.E. 2005. Determination of total monomeric anthocyanin pigment content of fruit juices, beverages, natural colorants, and wines by the $\mathrm{pH}$ differential method: Collaborative study. The Journal of AOAC INTERNATIONAL 88(5): 1269-1278.

Lin, M.J., Humbert, E.S. \& Sosulski, F.W. 1974. Certain functional properties of sunflower meal products. Journal of Food Science 39(2): 368-370.

Liu, S.C., Lin, J.T. \& Yang, D.J. 2009. Determination of cisand trans- $\alpha$-and $\beta$-carotenoids in Taiwanese sweet potatoes (Ipomoea batatas (L.) Lam.) harvested at various times. Food Chemistry 116(3): 605-610.

Mohanraj, R. \& Sivasankar, S. 2014. Sweet potato (Ipomoea batatas [L.] Lam) - A valuable medicinal food: A review. Journal of Medicinal Food 17(7): 733-741.

Prosky, L., Asp, N.G., Furda, I., DeVries, J.W., Schweizer, T.F. \& Harland, B.F. 1985. Determination of total dietary fiber in foods and food products: Collaborative study. Journal Association of Official Analytical Chemists 68(4): 677-679.
Shekhar, S., Mishra, D., Buragohain, A.K., Chakraborty, S. \& Chakraborty, N. 2015. Comparative analysis of phytochemicals and nutrient availability in two contrasting cultivars of sweet potato (Ipomoea batatas L.). Food Chemistry 173: 957-965.

Singh, S., Riar, C.S. \& Saxena, D.C. 2008. Effect of incorporating sweet potato flour to wheat flour on the quality characteristics of cookies. African Journal of Food Science 2: 65-72.

Singh, J., Dartois, A. \& Kaur, L. 2010. Starch digestibility in food matrix: A review. Trends in Food Science \& Technology 21: 168-180.

Tang, Y., Cai, W. \& Xu, B. 2015. Profiles of phenolics, carotenoids and antioxidative capacities of thermal processed white, yellow, orange and purple sweet potatoes grown in Guilin, China. Food Science and Human Wellness 4(3): 123-132.

Torres, A., Frias, J., Grantito, M. \& Vidal-Valverde, C. 2007. Germinated Cajanus cajan seeds as ingredients in pasta products: Chemical, biological and sensory evaluation. Food Chemistry 101(1): 202-211.

Trinidad, P.T., Mallillin, A.C., Loyola, A.S., Sagum, R.S. \& Encabo, R.R. 2010. The potential health benefits of legumes as a good source of dietary fibre. British Journal of Nutrition 103(4): 567-574.

Wang, A., Li, R., Ren, L., Gao, X., Zhang, Y., Ma, Z., Ma D. \& Luo, Y. 2018. A comparative metabolomics study of flavonoids in sweet potato with different flesh colors (Ipomoea batatas (L.) Lam). Food Chemistry 260: 124-134.

Wanjuu, C., Abong, G., Mbogo, D., Heck, S., Low, J. \& Muzhingi, T. 2018. The physiochemical properties and shelf-life of orange-fleshed sweet potato puree composite bread. Food Science \& Nutrition 6(6): 1555-1563.

Xu, A., Guo, K., Liu, T., Bian, X., Zhang, L. \& Wei, C. 2018. Effects of different isolation media on structural and functional properties of starches from root tubers of purple, yellow and white sweet potatoes. Molecules 23(2135): 1-17.

Yadav, B.S., Yadav, R.B., Kumari, M. \& Khatkar, B.S. 2014 Studies on suitability of wheat flour blends with sweet potato, colocasia and water chestnut flours for noodle making. $L W T$ - Food Science and Technology 57(1): 352-358.

Zhang, L., Zhao, L., Bian, X., Guo, K., Zhou, L. \& Wei, C. 2018. Characterization and comparative study of starches from seven purple sweet potatoes. Food Hydrocolloids 80 168-176.

Department of Food Science and Biotechnology

Gachon University

Seongnam 13120

Republic of Korea

*Corresponding author; email: ytlee@gachon.ac.kr

Received: 19 December 2019

Accepted: 23 March 2020 